\title{
RISKS OF THE IMPACT OF DIGITAL TECHNOLOGIES ON THE MAIN FUNCTION OF THE INSTITUTE OF EDUCATION
}

\author{
(C) Andrey Yu. Smirnov
}

\author{
Branch of the Air Force Academy named after Prof. Zhukovsky and Yu.A. Gagarin, \\ Syzran, Samara region, Russian Federation \\ say69@bk.ru
}

The main goal of this article is to analyze the risks of mass introduction of digital technologies and their impact on the main function of the social institution of education. Regardless of the historically established scientific and conceptual approaches to the institutional structure of society, the main function of the institution in question is the educational one, which is usually divided into education and training, which are not synonyms, as many believe. Each of these elements has its own content and objectives. They determine the main social and status characteristics of a person, influencing his subsequent existence in society. This article contains a brief description of the digitalization process as the main phenomenon of our time, the significance of its impact on the development of all spheres of society is determined. The specificity is also indicated and the contradictory nature of the course of this process is shown: namely, the negative component of the influence of digitalization on the main function of the social institution of education is revealed. The significance of digital technologies is quite clearly marked and has a real manifestation in the life of every modern person. Learning and education processes are no exception. With the massive introduction of an innovation, along with the positive, there are always possible negative consequences. As a rule, they are probabilistic, often unpredictable. The materials of the scientific article contain the results of research demonstrating the specific manifestation of the predicted negative consequences and their objective existence in the modern education system.

Key words: institute of education, educational function, digitalization, digital technologies, intelligent technologies, risks of introducing digital technologies.

\section{[А.Ю. Смирнов Риски влияния цифровых технологий на основную функцию института образо- вания]}

Основная цель данной статьи - анализ рисков массового внедрения цифровых технологий и их влияния на основную функцию социального института образования. Независимо от исторически сложившихся научно-концептуальных подходов к институциональному строению общества основной функцией рассматриваемого института является образовательная, которую принято делить на образование и обучение, не являющиеся синонимами как считают многие. Каждый из этих элементов имеет собственное содержание и задачи. Они определяют основные социально-статусные характеристики человека, влияющие на его последующее бытие в социуме. В данной статье содержится краткая характеристика процесса цифровизации как основного феномена современности, определена значимость его воздействия на развитие всех сфер общества. Обозначена также специфика и показан противоречивый характер протекания этого процесса: а именно раскрыта негативная составляющая влияния цифровизации на основную функцию социального института образования. Значимость цифровых технологий достаточно четко обозначена и имеет реальное проявление в жизни каждого современного человека. Процессы обучения и получения образования не являются исключением. При массовом внедрении новшества наряду с позитивом всегда присутствуют возможные негативные последствия. Как правило, они носят вероятностный, зачастую непредсказуемый характер. Материалы научной статьи содержат результаты исследований, демонстрирующие конкретное проявление прогнозируемых негативных последствий и их предметное существование в современной системе образования.

Ключевые слова: институт образования, образовательная функция, цифровизация, цифровые технологии, интеллектуальные технологии, риски внедрения цифровых технологий.

Andrey Yu. Smirnov - Lecturer, Branch of the Air Force Academy named after Prof. Zhukovsky and Yu.A. Gagarin, Syzran, Samara region, Russian Federation. 
Смирнов Андрей Юрьевич - преподаватель, фрилиал Военного учебно-научного центра Военновоздушных сил «Военно-воздушная академия им. проф. Н.Е. Жуковского и Ю.А. Гагарина», г. Сызрань, Самарская область, Российская Федерация.

The modern world community has undergone profound changes over the past 25 years. The mechanisms of its functioning at the end of the 20th century - the beginning of the 30th decade of the 21st century differ significantly from the previous ones; the largescale rates of their transformation were not known earlier in the history of mankind. World scientists associate this dynamics with the emergence and development of information and communication technologies (ICT), the basis of which is the digitalization of information flows. Currently, most people on Earth cannot imagine their existence without the comprehensive and ubiquitous Internet. For many, virtual reality has become an objective reality of everyday life.

In the original sense, digitalization is a transition from an analog form of information transmission to a digital one [4, p.17]. A person receives information about the surrounding reality in the form of an analog signal, and his senses do not perceive a significant part of this information. The transmission of analog signals over a certain distance was mastered by people for a long time. A natural need has become the necessity to accelerate the transfer of any information and increase its volume. Only after the Second World War, with the development of scientific and technological progress, this problem found its solution. It was embodied in the second half of the 20th century within the framework of the analogue that appeared in the West, and later on the Internet itself. Information transmission was carried out by means of a signal converted into digital form. This innovation allowed to infinitely increase the speed and volume of its transmission and was the beginning of the entry into the era of digitalization.

The resulting Network, called the Internet, or the World Wide Web, embodied two main directions for solving vital problems. The first is high-speed transmission, processing and storage of large amounts of information. The second is the creation of technical devices that ensure the performance of these functions. Thanks to this, the two originally separate processes merged into a single whole. This merger led to the emergence of the modern digital world [6, p. 33-34]. The concept of digital technologies appeared, and a discussion around the problem of their impact on society began in the world scientific community.

Starting as a technological process, digitalization has acquired a multilevel character and has moved to a socially significant plane. The degree and direction of its influence on the life of mankind are considered by the authors of scientific and scientific-journalistic works in different ways. Some consider digitalization a positive process, others - a negative manifestation of social life. In a number of publications, views on this problem are sharply polarized: alternative options are not recognized. For example, the authors of the book "Abundance: the future will be better than you think" consider the emergence and development of digital technologies as the key to solving all the troubles and problems of the coexistence of the world community [3, p. 31]. In contrast to their opinion, the point of view is being strengthened, within which digitalization is compared with the beginning of the "apocalypse" of humanity.

Regardless of the views, the majority of scientists and publicists agree that the digitalization of all spheres of social life is of a global transformational nature for modern civilization. The President of the World Economic Forum in Davos, Klaus Schwab, who has a unique opportunity to generalize the experience and views of the world's leading experts on the problem under consideration, believes that humanity is entering the era of a new 
"Fourth Industrial Revolution". The previous three industrial revolutions have brought about global shifts in the functioning of society on Earth. Assessing the role of the widespread adoption of digital technologies, he states: "We are at the origins of a revolution that will fundamentally change our life, our work and our communication. In terms of scale, volume and complexity, this phenomenon, which I consider the fourth industrial revolution, has no analogues in all the previous experience of mankind" [12, p. 8].

The transformation of all spheres of social life under the influence of digitalization predictably entails changes in the process of functioning of the main social institutions of society. The Institute of Education, being one of the main ones, is no exception. The controversy over the significance and direction of the impact of digital technologies on the constituent elements of its structural and functional basis is one of the most common topics of discussion at the present time. In this article, the author does not consider the process of transformation of a social institution as a whole, but only touches on the changes associated with its main function - educational. This dynamic element of the structure of the institution of education can be conditionally divided into two interdependent, but not synonymous components. The first is education. A category that characterizes the acquisition of a certain level of knowledge, skills and abilities that determine the future social status of a person's functioning in society. The second is the learning process, which is a predetermined, formalized, state-regulated process. It determines the level of the content of the transfer of knowledge, as well as the methods of teaching it, enshrined in Federal educational standards, Work plans, Curriculum, etc. Describing the learning process, E. Giddens wrote that it is: "a formal process by which certain types of knowledge and skills are transmitted in accordance with pre-developed curricula" [2, p. 127]. When analyzing the problem under consideration, it is necessary to take into account the impact of digitalization on both components, then its results will be objective.

The positive consequences of the spread of the practical use of digital technologies in the educational sphere are well known. All major world and Russian media, and primarily the Network, constantly officially inform the public about this phenomenon. It is customary to refer to the main, generally recognized pragmatic characteristics of digital implementation: the flexibility of using this form of information in time and space; unlimited reproducibility of existing information; variability, i.e. the ability to make newly identified, urgent changes to existing data; selectivity, providing a free search for the necessary information; individualization, which allows each person to work with information individually [9, p. 47]. In the educational sphere, all of the above contributes to the solution of the main educational problem, which is to eliminate the inequality of opportunities for obtaining quality education by various categories of the population of any country. The spread of this trend is facilitated by the emergence of the following conditions: providing students with equal access to high-quality open digital educational resources and teaching materials; improvement of materials and organization of distance learning using distance learning technologies; advice and assistance in choosing a place for continuing education using the Internet; dissemination of the model of the personalized organization of the educational process $[9$, p. 56].

One of the tasks of this work was the analysis of socio-philosophical works reflecting a less well-known and not always advertised area of knowledge associated with the risks of the impact of digitalization on the educational function of the institution of education. We will focus on the study of works that use an objective approach and are based on scientific evidence.

Russian scientists have also made a significant contribution to the study of digitalization problems and the impact of digital culture on the processes taking place in the educa- 
tion system. The authors of scientific works that state the negative impact of digitalization are: N.B. Strelkova, A.Yu. Uvarov, T.S. Akhromeeva, D.I. Dubrovsky, V.A. Kutyreva, E.V. Maslanova, D.A. Macheret, Yu. Petrunin, A.I. Rakitova, G.L. Tulchinsky, A.G. Chernyshova, N.I. Kasperskaya, etc. Among foreign authors of scientific and scientificjournalistic works considering the negative impact of digital technologies on a person, one can note: R. Emerson, F. Davis, S. Tarkle, B. Friedman, M. Spitzer, N. Karr and others.

The majority of scientists, supporters of the negative impact of digital technologies on people, consider irreversible changes in the course of cognitive mental processes of the human brain (thinking and memory) to be the main risk of introducing digitalization into the educational sphere. For the first time, the concept of "digital dementia" was introduced into the public lexicon by doctors in South Korea, a country that is considered to be the world leader in the implementation of information technologies in the educational sphere at all levels [13, p. 180]. The main identified symptoms of the newly emerging disease in young people are: lack of ability to concentrate thoughts; distraction of attention; memory impairment; a decrease in the depth of emotions and a general dullness of feelings [13, p. 181].

Nicholas Carr, author of the world-famous scientific and journalistic book "Empty: What the Internet is doing to our brains", provides a classification of technologies that have significantly influenced the history of human development. He examines the direction and degree of their influence on this process. N. Carr considers computerization, informatization and digitalization to be intellectual technologies. Describing them, he writes: "... it is intellectual technologies that have had the most significant and lasting impact on what and how we think. These are the nearest tools that we use for self-expression, the formation of personal and social identity and for the development of relationships with others [5, p. 53].

The opinion of Manfred Spitzer, head of the psychiatric clinic in UIm (Germany), who has been engaged in scientific analysis of the changes that occur in the human brain during training for more than 20 years, coincides with the opinion of N. Carr. In the book AntiBrain: Digital Technologies and the Brain, which sparked a worldwide discussion, the scientist states: "... our brain is in the process of continuous change, and this inevitably leads to the conclusion: daily communication with digital mass media and communications cannot, but influence us, ordinary users" [13, p. eight]. In the scientific and journalistic works of N. Carr and M. Spitzer, based on the results of actually carried out in this direction of scientific research, the diagnosis of digital dementia and its symptoms are confirmed and proven in a significant part of the youth of the developed digitalized community.

In Russia, the majority of teachers of non-rating universities on the pages of official and non-official information sources determine the significant features of modern applicants and first-year students. They can be conditionally divided into two components. The first of them is the characteristic of the personality of a young person inherent in most of the trainees. And the second is showing significant and relevant characteristics of intellectual and ideological features. The first category includes general illiteracy in the knowledge of one's own language and spelling culture [10]. The second aspect is the lack of the ability to memorize the middle block of educational information, high-quality reproduction and analysis of this material. Without digital technologies, without Google, learners cannot think and make decisions for themselves [1].

Scientists consider the replacement of the function of handwriting with digital technologies to be significant risks of the impact of digitalization on education. By replacing the main cultural skill of a man, i.e. reading and writing (written speech), digital technologies hinder the development of a person's external and internal speech. Almost 100 years ago, the Soviet psychologist L.S. Vygodsky wrote: "Speech, which is at first a means of communication, a means of communication, a means of organizing collective behavior, later 
becomes the main means of thinking and all higher mental functions, the main means of building a personality" [7, p. 223].

Some scholars believe that the apparent anonymity of the information and digital environment of the Internet, in which young people "live", is a significant risk of mass introduction of digital technologies into the educational sphere. Among the bulk of students there is an opinion that the Network allows them to replace real mental activity with its virtual analogue to generate reports on the educational tasks put forward. Special programs designed to combat plagiarism are not always successful [13, p. 80]. Constant use of Internet services creates a distorted view of the cognitive process. For the majority of students, the creation of a scientific work is associated with pressing the desired button on the computer keyboard [8, p. 15]. The result of this self-deception is the future inability to independently analyze, characterize and solve emerging educational and scientific, as well as everyday professional problems.

An overview of the significant risks of introducing digital technologies into the educational environment is limited by the volume of this article. They can also include the imaginary virtual satisfaction of social communication, leading to the loneliness of the individual in real life, the market nature of the introduction of digital technologies, etc.

Definite conclusions on this issue should be based on objective facts. Contradictory opinions about the prospects and risks of introducing digital technologies into the social institution of education have a sufficient research base confirming their mutual rationality in the modern world. Undoubtedly, the solution to this problematic issue should be of a compromise nature, therefore, it can be determined that:

1) the specificity of the manifestation of positive or negative aspects of the introduction of digital technologies into the main functional sphere of the institution of education is of a predictive nature;

2) sufficiently significant negative features of the introduction of digital technologies can be found in scientific research carried out in the field of school and preschool education. This determines the main direction for further in-depth analysis of this problem;

3 ) it is vitally important, regardless of the commercial nature of the current stage of the functioning of the social institution of education, to remember the ethics of introducing new technologies into this process. First of all, this concerns the innovations of intellectual content, which directly affect the thinking of a person.

The modern state policy in the field of institutional regulation of the educational sphere of Russian society is aimed at maintaining the world standards of its functioning. In recent decades, public opinion has been actively formed about the significant lag of our country behind the civilized West. However, many scientists disagree with this trend. The opinion of Doctor of Political Sciences A.G. Chernyshov, who writes that Russia's delay in the digitalization of society from the world's leading countries gives the state an undeniable advantage in terms of assessing its impact on society. In our country, there is a unique opportunity not to repeat the mistakes of the pioneers, primarily in terms of preserving and increasing human capital [11, p. 20]. Decision-making remains with the state and its policy pursued in the institutional sphere of Russian education.

\section{Лumepamypa}

1. Высшее образование в СССР и сейчас [Электронный ресурс]. Режим доступа: https://pikabu.ru/story/vyisshee-obrazovanie-v-sssr-i-seychas-5430570. Дата обращения: 14.15.2021. 
2. Гидденс Э., Саттон Ф. Основные понятия в социологии / пер. с англ. Е. Рождественской, С. Гавриленко; под науч. ред. С. Гавриленко. М.: Изд. дом Высшей школы экономики, 2019. 528 с.

3. Диамандис П., Котлер С. Изобилие: будущее будет лучше, чем вы думаете / пер. с англ. В. Дегтяревой. М.: АСТ, 2018. 608 с.

4. Индустрия российских медиа: цифровое будущее [Академические монографрии]. - М.: Медиа Мир, 2017. 160 с.

5. Карр Н. Пустышка: что интернет делает с нашими мозгами / пер. с английского П. Миронов. Best Business Books, 2012. 253 с.

6. Ракитов А.И. Человек в оцифрованном мире // Философия науки. Академия гуманитарных исследований (Москва). 2016. №6. С. 32-46.

7. Собрание сочинений. В 6-ти т. Т. 4. Детская психология / Под ред. Д.Б. Эльконина. М.: Педагогика, 1984. 432 с.

8. Строков А.А. Цифровизация образования: проблемы и перспективы // Вестник Мининского университета. 2020. Т. 8. № 2. С. 15.

9. Трудности и перспективы цифровой трансформации образования / А. Ю. Уваров, Э. Гейбл, И. В. Дворецкая и др.; под ред. А. Ю. Уварова, И. Д. Фрумина; Нац. исслед. ун-т «Высшая школа экономики», Ин-т образования. М.: Изд. дом Высшей школы экономики, 2019. 343 с.

10. Фесенко О.П., Божко И.Ю. Проблемы языковой грамотности студентов как результат переориентации современной образовательной парадигмы [Электронный ресурс]. Режим доступа: https://ulspu.ru/upload/img/medialibrary/f7e/fesenko_bozhko_omsk_statya.pdf. Дата обращения: 26.05.2021.

11. Чернышов А.Г. Стратегия и философияя цифровизации // ВЛАСТЬ. 2018. Том: 26. № 5. C. 13-21.

12. Шваб К. Четвертая промышленная революция. М.: «Эксмо», 2016. 138 с.

13. Шпитцер М. Антимозг: цифровые технологии и мозг / пер. с немецкого А.Г. Грищина. М.: АСТ, 2014. 288 с.

\section{References}

1. Vyssheye obrazovaniye $\mathrm{v}$ SSSR i seychas [Higher education in the USSR and now]. Available at: https://pikabu.ru/story/vyisshee-obrazovanie-v-sssr-i-seychas5430570 (accessed 14 May 2021) (in Russian).

2. Giddens E., Satton F. Osnovnyye ponyatiya v sotsiologii [Basic concepts in sociology]. Moscow: Izd. dom Vysshey shkoly ekonomiki, 2019. 528 p. (in Russian).

3. Diamandis P., Kotler S. Izobiliye: budushcheye budet luchshe, chem vy dumayete [Abundance: the future will be better than you think]. Moscow: AST, 2018. 608 p. (in Russian).

4. Industriya rossiyskikh media: tsifrovoye budushcheye [ndustry of Russian media: digital future]. Moscow: Media Mir, 2017. 160 p. (in Russian).

5. Karr N. Pustyshka: chto internet delayet s nashimi mozgami [What the Internet is Doing to Our Brains]. Best Business Books, 2012. 253 p. (in Russian).

6. Rakitov A.I. Chelovek $v$ otsifrovanom mire. Filosofiya nauki. Akademiya gumanitarnykh issledovaniy (Moskva) [A person in a digitalized world. Philosophy of Science. Academy of Humanitarian Research (Moscow)]. 2016. No. 6. pp. 32-46 (in Russian). 
7. Sobraniye sochineniy. V 6-ti t. T. 4. Detskaya psikhologiya [Collected Works. In 6 volumes. V. 4. Child psychology]. Moscow: Pedagogika, 1984. 432 p. (in Russian).

8. Strokov A.A. Tsifrovizatsiya obrazovaniya: problemy i perspektivy [Digitalization of education: problems and prospects]. Vestnik Mininskogo universiteta. 2020. V. 8. No 2. p. 15 (in Russian).

9. Trudnosti i perspektivy tsifrovoy transformatsii obrazovaniya. A. YU. Uvarov, E. Geybl, I. V. Dvoretskaya i dr. Nats. issledovatelskiy universitet «Vysshaya shkola ekonomiki», Institut obrazovaniya [Difficulties and prospects of digital transformation of education. National Research University Higher School of Economics, Institute of Education]. Moscow: Izd. dom Vysshey shkoly ekonomiki, 2019. 343 p. (in Russian).

10. Fesenko O.P., Bozhko I.YU. Problemy yazykovoy gramotnosti studentov kak rezultat pereoriyentatsii sovremennoy obrazovatelnoy paradigmy [Problems of linguistic literacy of students as a result of reorientation of the modern educational paradigm]. Available at: https://ulspu.ru/upload/img/medialibrary/f7e/fesenko_bozhko_omsk_statya.pdf (accessed 26 May 2021) (in Russian).

11. Chernyshov A.G. Strategiya i filosofiya tsifrovizatsii [Strategy and philosophy of digitalization]. VLAST. 2018. V. 26. No. 5. pp. 13-21 (in Russian).

12. Shvab K. Chetvertaya promyshlennaya revolyutsiya [The fourth industrial revolution]. Moscow: «Eksmo», 2016. 138 p. (in Russian).

13. Shpittser M. Antimozg: tsifrovyye tekhnologii i mozg [Antibrain: digital technologies and the brain]. Moscow: AST, 2014. 288 p. (in Russian). 